\title{
(DES)ENVOLVIMENTO REGIONAL, FRONTEIRA E O ESPAÇO DO AGRONEGÓCIO NO TOCANTINS
}

\section{REGIONAL INVOLVEMENT, FRONTIER AND THE SPACE OF AGRIBUSINESS IN TOCANTINS}

\author{
Roberto de Souza Santos \\ Doutorado em Geografia pela UNESP - Rio Claro -SP. Professor efetivo do Programa de Pós-graduação \\ da Universidade Federal do Tocantins e curso de Geografia Campus Porto Nacional - TO. \\ robertosantos@uft.edu.br
}

\section{Resumo}

O presente artigo procura levantar uma discussão teórico-crítica sobre o agronegócio e os seus impactos socioeconômicos em municípios que destacam na atividade econômica do agronegócio no Tocantins. Os procedimentos metodológicos basearam-se no método qualitativo e em uma revisão bibliográfica. $\mathrm{O}$ debate teórico analisou a relação entre a atividade econômica do agronegócio e as condições sociais da população local. Os procedimentos metodológicos foram organizados e executados a partir de uma análise teórico-crítica sobre os desdobramentos sociais na fronteira capitalista no Tocantins. $\mathrm{O}$ que se percebe é que os índices de qualidade de vida social dos municípios analisados, não correspondem aos índices recomendados pela Organização das Nações Unidas. O modelo de (des)envolvimento fomentado pelas políticas de investimento é altamente excludente socialmente e, tem como objetivo manter a geopolítica territorial e contribuir para reprodução do capital.

Palavras-chave: Agronegócio. Fronteira capitalista. Indicadores sociais.

\begin{abstract}
This article seeks to raise a theoretical and critical discussion about agribusiness and its socioeconomic impacts in municipalities that stand out in the economic activity of agribusiness in Tocantins. The methodological procedures were based on the qualitative method and a literature review. The theoretical debate analyzed the relationship between the economic activity of agribusiness and the social conditions of the local population. The methodological procedures were organized and executed based on a theoreticalcritical analysis of the social developments on the capitalist frontier in Tocantins. What can be seen is that the indexes of quality of social life in the analyzed municipalities do not correspond to the indexes recommended by the United Nations. The (dis) involvement model fostered by investment policies is highly socially exclusive and aims to maintain territorial geopolitics and contribute to the reproduction of capital.
\end{abstract}

Keywords: Agribusiness. Capitalist frontier. Social indicators. 


\section{Introdução}

O objetivo do artigo é demonstrar e analisar os indicadores sociais a partir dos impactos sociais e econômicos da atividade econômica do agronegócio nos municípios de Campos Lindos, Formoso do Araguaia, Lagoa da Confusão, Pedro Afonso e Porto Nacional no período de 1991 a 2010, onde o agronegócio é muito dinâmico. Toda produção do material para a elaboração do artigo é resultado de pesquisas realizadas na pós-graduação da Universidade Federal do Tocantins (Mestrado em Geografia) a partir da execução do projeto Cidades, fronteiras e população tradicional: a construção da abordagem geográfica dos territórios tocantinense e goiano aprovado pelo CNPq/CAPES/Casadinho/Procad/Chamada Pública MCTI/CNPq/MEC/Capes - Ação Transversal nº 06/2011, já finalizado e, do projeto da Chamada Universal - MCTI/CNPq No 14/2014, com o título Fronteira e modernização agrícola na região nordeste do Tocantins: uma análise dos impactos socioterritoriais nas comunidades tradicionais, ainda em execução.

$\mathrm{O}$ texto trabalha com indicadores sociais para mensurar os impactos sociais e econômicos da atividade econômica do agronegócio nos municípios analisados. Embora, os indicadores sociais pertencem ao gênero quantitativo, podem ser usados para mensurar aspectos qualitativos. Sua efetividade para a explicação dos fenômenos analisados difere no espaço e no tempo. Portanto, um indicador útil em um determinado lugar e época, pode não ser útil para outra região. Segundo Procópio, et ali. (2009), um indicador social é uma medida em geral quantitativa dotada de significado social substantivo, usado para substituir, quantificar ou operacionalizar um conceito social abstrato, de interesse teórico (para pesquisa acadêmica) ou programático (para formulação de políticas). É um recurso metodológico, empiricamente referido, que informa algo sobre um aspecto da realidade social. Os indicadores sociais indicam ou apontam uma determinada tendência de evolução das condições sociais e trabalham com dados estatísticos abstratos e com coeficiente de media que pode não refletir o real, que, em princípio, precisamos refletir de forma mais crítica sobre a análise de sua metodologia.

A discussão teórico-metodológica procedeu-se de duas formas: um debate teórico a partir da interpretação do referencial bibliográfico utilizado e trabalhado e das experiências construídas durante a execução das pesquisas. A abordagem dialética orientou os procedimentos metodológicos da pesquisa, cuja análise valeu-se de aspectos 
materiais e sociais, partindo da premissa de que a realidade só é compreendida em direção à totalidade. As pesquisas de campo foram executadas pelo levantamento de dados primários no trabalho de campo e dados secundários através da pesquisa documental em órgãos oficiais públicos como o IBGE e o Atlas de Desenvolvimento Humano (PNUD). A pesquisa de campo procedeu-se a partir da aplicação de perguntas abertas e observações em lócus.

O trabalho de campo realizado pelas entrevistas teve por objetivo colher informações para aprofundar a análise do objeto de estudo. As entrevistas foram necessárias para complementar as informações da pesquisa documental. Foram entrevistados o secretario da Secretaria Estadual de Planejamento do Tocantins-SEPLAN, os secretários municipais de assistência social dos municípios analisados e o diretor da empresa Campos Verde e o presidente da Cooperativa Coperjava em formoso do Araguaia. A pesquisa documental permitiu levantar dados estatísticos do IBGE e do Atlas de desenvolvimento Humano para a tabulação, organização, mensuração e avaliação dos dados trabalhados. Outra pesquisa documental utilizada foi a utilização de shape para georreferenciamento e elaboração de mapas para cartografar e ilustrar o objeto de estudo. As fontes secundarias foram coletadas no Atlas de Desenvolvimento Humano e no IBGE e na SEPLAN-TO.

Para realização da pesquisa foi escolhido os municípios de Campos Lindos, Formoso do Araguaia, Lagoa da Confusão, Porto Nacional e Pedro Afonso, pelo fato destes serem eleitos pelo capital do agronegócio como espaço estratégico para a sua reprodução. A escolha deu-se também pelo fato destes municípios terem a atividade econômica do agronegócio muito atuante e com destaque sobre os demais municípios do Tocantins. Portanto, os impactos socioeconômicos do agronegócio destes municípios são potencialmente, mais real para ser analisados. Após o levantamento bibliográfico e dos dados primários e secundários procedeu-se a compilação, organização das ideias e interpretação dos dados e informações levantadas disponíveis na literatura adotada. A partir dos procedimentos teórico-metodológicos qualitativos descritos, chegou-se aos resultados que viabilizaram a redação final do artigo.

O texto está estruturado em cinco tópicos. O primeiro trata das bases teóricoconceituais que definem os conceitos teóricos sobre frente de expansão, fronte pioneira e desenvolvimento local, regional e sustentável. O segundo tópico aborda sobre os 
programas de investimento e eixos de (des)envolvimento regional no Tocantins, com destaque do POLOAMZONIA, POLOCENTRO e POLONOROESTE e da rodovia BR153 e a ferrovia Norte-Sul. O terceiro tópico trata-se da caracterização dos municípios analisados, os quais são considerados estratégicos pelo agronegócio. O quarto tópico aborda sobre o agronegócio e (des)envolvimento regional e humano nos municípios analisados. O quinto tópico procura concluir as observações e constatações inferidas resultantes da execução da pesquisa.

\section{Bases teórico-conceituais}

Dentre os adjetivos usados para o termo desenvolvimento, temos econômico, regional, local, sustentável e social. Do ponto de vista econômico, a palavra desenvolvimento representa em termos quantitativos, indica ideia de crescimento do PIB e de renda, por exemplo. Segundo Oliveira (2002), sob o prisma econômico, desenvolvimento é aumento do fluxo de renda real, isto é, incremento na quantidade de bens e serviços por um período. Considera desenvolvimento econômico como crescimento econômico (incrementos positivos no produto) acompanhado por melhorias do nível de vida dos cidadãos e por alterações estruturais na economia.

Antes da noção teórica de desenvolvimento regional, é bom que se entenda, a noção de região. Bezzi (2004) comenta que o conceito de região tem dois grupos fundamentais: as formulações convencionais (positivistas) que caracterizam-se por trabalhar com base na abstração do sistema social, que está na origem da formação regional, com isso formulam-se leis de caráter universal, sem considerar o condicionamento histórico do objeto que se pretende estudar. Sob este enfoque temos as teorias da Escola Alemã (Johann Heinrich von Thünen, August Lösch e Walter Christaller) e as teorias da Escola Francesa (François Perroux e Jacques Raoul Boudeville). O outro grupo são as concepções avançadas (materialismo histórico dialético) caracterizam-se por formulação a existência de um sistema social com determinantes históricos. O espaço não é neutro em relação ao tipo de sociedade que ali localiza. O sistema social é considerado em sua historicidade. Nestas formulações, encontra-se Francisco de Oliveira, José Luís Coraggio, Alain Lipietz entre outros.

O termo de desenvolvimento regional é um conceito teórico derivado do conceito de região. No campo da ciência geográfica destaca o geógrafo Walter Christaller de 
inspiração positivista que trabalha com a teoria do lugar central. No Brasil, temos o geógrafo Speridião Faissol de inspiração neopositivista, um dos representantes da Nova Geografia que trabalhou a geografia regional no âmbito quantitativo. E a geógrafa Bertha Koiffmann Becker que trabalhou desenvolvimento regional mais direcionado com a Amazônia. A noção de desenvolvimento regional se constrói teoricamente a partir destes teóricos economistas e geógrafos. A noção de desenvolvimento regional do ponto de vista operacional, foi sistematicamente trabalhada durante o Estado desenvolvimentista. Um desenvolvimento inspirado em políticas keynesianas. Operacionalmente, a partir de políticas públicas, os postulados sobre desenvolvimento regional foram aplicados para garantir a expansão espacial do modo de produção capitalista e sobretudo, o desenvolvimento regional em determinada porções da sociedade capitalista. Muito usado no século XX.

Ao contrário de desenvolvimento regional, a noção de desenvolvimento local, foi um termo usado no final do século passado e no atual, em que procura estabelecer políticas de desenvolvimento local compartilhada entre os diversos atores políticos e sociais e a parceria entre poder público e a iniciativa privada. Segundo Manfré (2019) definir o desenvolvimento local como um conjunto de diversas dinâmicas que se relacionam (social, econômica, política e cultural), atuantes em um território demarcado localmente. É um paradigma do desenvolvimento endógeno e bottom-up (de baixo para cima) que se liberta das políticas nacionais, buscando sua potencialidade e capacidade de desenvolver-se. Para Fauré; Hasenclever (2007), o desenvolvimento local é o encontro de potencialidades localizadas, exploradas ou a explorar, com o objetivo de valorizar os recursos locais. Segundo Martins (2002) o desenvolvimento local é uma organização comunitária em torno de um planejamento, por uma perspectiva de construção social.

Em uma discussão crítica podemos afirmar que o conceito de desenvolvimento local se forma a partir do discurso das políticas bilaterais do Banco Mundial. Segundo Lisboa (2007) o desenvolvimento local está centrado na ideologia do discurso do desenvolvimento a ser apreendida nas relações contraditórias do espaço do capital. Um discurso a partir dos anos 1980, tendo o Banco Mundial a instituição chave do ajuste estrutural em escala global e o seu papel veiculador da ideologia do desenvolvimento local. Os lugares se tornam interessantes, atrativos e úteis à acumulação e garantem 
mobilidade ao capital, isto é, a dimensão local traz o caráter dinâmico do território, sustentada na ideia da potencialidade dos lugares.

O discurso do desenvolvimento não é uma questão da promoção do bem-estar da sociedade, mas o de cumprir sua função ideológica de legitimação das relações de produção capitalistas. No Brasil, é a partir dos anos 1990, que é implementada uma política de desenvolvimento local para executar as políticas de ajuste estrutural obedecendo a cartilha do Banco Mundial. A reforma e descentralização do Estado, com destaque para o papel destinado ao território como ator do desenvolvimento e a emergência do desenvolvimento local como cenário econômico, político e social, afirma Lisboa (2007). Compartilhamos com este raciocínio do autor, sobre a interpretação de desenvolvimento local, em que é uma política focada no desenvolvimento capitalista em busca da mais valia. As políticas de desenvolvimento atrelada as intenções geopolíticas do Banco Mundial vão mais de encontro com os interesses da burguesia capitalista do que os interesses dos trabalhadores e da população local.

Com a crise do Estado desenvolvimentista por volta da década de 1980, o debate sobre desenvolvimento regional é substituído pelo debate do desenvolvimento sustentável, entretanto, o desenvolvimento local continua, mas em uma perspectiva do conceito sustentável. Segundo Christofoletti (1993), o termo desenvolvimento sustentável começou a ser utilizado no da década de 1970, quando da convenção realizada em Cocoyoca (1974) a respeito do desenvolvimento e ambiente. A Comissão Mundial Sobre Meio Ambiente e Desenvolvimento foi estabelecida em dezembro de 1983 pela Organização das Nações Unidas, a fim de compor uma agenda global. Baseado nas formulações do Relatório BrundtIand, constituindo o volume Our Common Futurc, elaborado pela Comissão Mundial Sobre Meio Ambiente e Desenvolvimento e publicado em 1987, tornou-se corrente o uso da expressão “desenvolvimento sustentável”. No Brasil, o debate sobre o desenvolvimento sustentável se deu na década de 1990, com a ECO-92, no Rio de Janeiro, com a preocupação em debater a distinção entre desenvolvimento e crescimento econômico.

Para Christofoletti (1993), a noção de sustentabilidade é voltada as atividades que podem ser realizadas continuadamente, a longo prazo. Segundo Oliveira (2002) o desenvolvimento sustentável está atrelado ao tripé: a sustentabilidade econômica que refere ao aumento na eficiência do sistema econômico; a sustentabilidade ecológica que 
concerne à preservação do meio ambiente sem comprometer a oferta dos recursos naturais necessários à sobrevivência humana e a sustentabilidade espacial que refere-se ao tratamento equilibrado da ocupação rural e urbana e, a melhor distribuição territorial das atividades econômicas. Christofoletti (1993) afirma que de modo mais genérico, o desenvolvimento sustentável constitui a diretriz ou conjunto de estratégias visando melhorar a qualidade de vida humana dentro dos limites de capacidade de suporte dos sistemas ambientais físicos. Há confusões quando se utilizam os termos "crescimento econômico", "crescimento econômico sustentável”, "desenvolvimento sustentável” e “uso sustentável” como sendo sinônimos, mas entre eles há diferenças conceituais.

O crescimento econômico significa que o produto nacional bruto per capita aumenta ao longo do tempo, mas não significa que o crescimento seja sustentado. $\mathrm{O}$ crescimento econômico sustentável significa que o produto nacional bruto per capita aumenta ao longo do tempo e o aumento não se encontra ameaçado pelo mecanismo de retroalimentação, em virtude dos impactos de ordem biofísica (poluição, problemas de recursos naturais) ou impactos de ordem social (pobreza, distúrbios sociais). O desenvolvimento sustentável significa que a utilidade ou bem-estar per capita aumenta ao longo do tempo com a permuta livre ou substituição entre o capital natural e o construído pelo homem, ou que a utilidade ou bem-estar per capita aumenta ao longo do tempo, sem que haja declínio na riqueza natural. O “uso sustentável” costuma ser aplicável somente a recursos renováveis, significando o uso desses recursos em quantidades compatíveis com sua capacidade de renovação, afirma Christofoletti (1993).

A expressão desenvolvimento tem outras interpretações teóricas como as positivistas e marxistas. A interpretação positivista refere mais a um aspecto econômico (quantitativo) e marxista mais para o aspecto social (qualitativo). Oliveira (2002), afirma que há duas correntes de pensamento econômico sobre o tema. A primeira define o crescimento como sinônimo de desenvolvimento, que diríamos por um viés positivista. Nesta corrente estão os modelos de crescimento da tradição clássica (Adam Smith, David Ricardo, etc.) e neoclássica (de inspiração teórica keynesiana). Enquanto na segunda, o crescimento é condição indispensável para o desenvolvimento, mas não é condição suficiente. Nesta corrente estão os economistas de orientação crítica, formados na tradição marxista ou cepalina, que conceitua o crescimento como uma simples variação quantitativa do produto, enquanto desenvolvimento é caracterizado por mudanças 
qualitativas no modo de vida das pessoas, nas instituições e nas estruturas produtivas. São exemplos dessa corrente os economistas Raul Prebisch e Celso Furtado.

O temo (des)envolvimento no texto refere-se a uma interpretação teórico-crítica, para questionar a concepção de desenvolvimento. A ideia de desenvolvimento sintetiza o projeto civilizatório, tanto pela via liberal e capitalista, como pela via social - democrata e socialista. Para Porto-Gonçalves (2011), desenvolvimento é o nome síntese da ideia de dominação da natureza, ser desenvolvido é ser urbano, é ser industrializado, enfim, é ser tudo aquilo que nos afaste da natureza e que nos coloque diante de constructos humanos, como a cidade, como a indústria. "A ideia de desenvolvimento está associada à modernidade - ser moderno é ser desenvolvido, é estar em desenvolvimento - e, também aqui, se olvida de que a modernidade é incompreensível sem a colonialidade", (PORTO - GONÇALVES, 2011, p.64).

A lógica do (des)envolvimento no plano da cultura e da vida social dos diversos povos considerados não modernos acontece, quando o modo de produção capitalista impõe a sua racionalidade econômica a partir do modelo de (des)envolver. Ou seja, o projeto capitalista moderno ao (des)envolver os povos ao mundo capitalista, destrói a cultura dos povos (não modernos). Para Porto-Gonçalves “(...) dês-envolve os diferentes habitats, os diferentes ecossistemas, os mais diferentes povos, culturas e regiões" (2011, p 85). (Des)envolver é tirar o envolvimento, a autonomia e a sustentabilidade da cultura dos diversos povos e, sobretudo, compromete os seus territórios. É incorporar as diversas culturas à cultura Ocidental a partir da destruição das outras culturas. A formação da fronteira capitalista, necessariamente, passa por essa lógica de (des)envolver a cultura e os territórios das comunidades indígenas, ribeirinhos, camponeses. $\mathrm{O}$ modo de produção capitalista ao se (des)envolver os sujeitos sociais, individualiza-os.

O debate sobre fronteira de expansão e frente pioneira, o sociólogo José de Souza Marins faz apontamentos teóricos a respeito. Para o sociólogo José de Souza Martins os conceitos de fronteira de expansão e frente pioneira, são noções distintas. A partir deste pressuposto, Martins procura fazer um debate teórico sobre as noções de fronteira de expansão e frente pioneira entre geógrafos e antropólogos. Para o referido autor, os geógrafos nos anos 1940 nomearam fronteira de zona pioneira, outras vezes frente pioneira. Para Martins (1997) quando os geógrafos abordam frente pioneira, indica uma 
das faces da reprodução ampliada do capital: terra como mercadoria, negócios imobiliários - fronteira capitalista.

Segundo Martins (1996), Monbeig define os índios alcançados (e massacrados) pela frente pioneira no Oeste de São Paulo, como precursores dessa mesma frente, como se estivessem ali transitoriamente, à espera da civilização que acabaria com eles. A ênfase original de suas análises estava no reconhecimento das mudanças radicais na paisagem pela construção das ferrovias, das cidades, pela difusão da agricultura comercial em grande escala, como o café e o algodão. As concepções de frente de expansão e de frente pioneira são apenas designações através das quais os pesquisadores reconhecem face dos diferentes modos de analisar como os civilizados se expandem territorialmente. (MARTINS, 1996).

Geógrafos como Pierre Monbeig, Leo Wabel e outros nos anos de 1940 e 1950 já faziam o debate como recomenda José de Souza Martins. Suas preocupações teóricas com o indígena na fronteira tornaram-se objeto de análise. Quanto aos antropólogos, Martins afirma que nos anos 1950, definem essas frentes de deslocamento da população "civilizada" e das atividades econômicas de algum modo reguladas pelo mercado, como frente de expansão. Para Darcy Ribeiro, as frentes na Amazônia constituem fronteiras civilizatórias. Frente de expansão é conhecida por antropólogos, historiadores e sociólogos.

Segundo Nogueira (2013), no entendimento de Monbeig, as frentes pioneiras paulistas têm no imaginário da expansão territorial da sociedade brasileira, desde ao menos a Era Vargas, iniciada em 1930, a compreensão do processo de formação do país à integração do território. Isto é, ao imperialismo interiorizado exercido dentro dos limites do Estado nacional e por ele incentivado em programas colonizadores oficiais como a Marcha para o Oeste. Certo que essa ideia busca compreender, inicialmente, o modo como o tema das frentes pioneiras foi analisado no Brasil por Pierre Monbeig.

Monbeig ressalta a sobreposição de circunstâncias políticas e econômicas mundiais, regionais e locais num complexo e intrincado jogo de escalas dentro do contexto da fronteira, onde há formas muito distintas de organização territorial, influenciando diretamente nos movimentos de conquista e ocupação de terras. Sobre a fronteira da Marcha para o Oeste em meados da década de 1940, Monbeig observa que: 
Reduzir a marcha para o Oeste a um fenômeno local, contentar-se com explicála por circunstâncias estritamente brasileiras, seria restringir abusivamente seus quadros e não enxergar mais que seus aspectos estreitos. Desde o seu início, a Marcha para o Oeste foi um episódio da expansão da civilização capitalista, surgida nas duas margens do Atlântico. (MONBEIG, 1952, p.105).

Ou seja, segundo Monbeig (1992) a Marcha para o Oeste contribuiu para a fronteira no Oeste e para o Norte brasileiro, como forma da ocupação humana e econômica e, sobretudo, essa fronteira deve ser entendida no contexto maior, o da civilização capitalista.

Diante deste ensaio teórico, o conceito de frente pioneira analisado por Pierre Monbeig (1992) e Martins (1996, 1997) está de acordo com as orientações colocadas de fronteira como um espaço do conflito social e étnico. No contexto amazônico, debater este conceito se justifica pelo fato da Amazônia ser um espaço que atualmente, o capitalismo encontra-se em expansão. Ao mesmo tempo em que de um lado, temos o agronegócio baseado na biotecnologia e na biogenética, de outro temos, economias baseadas ainda na extração tradicional e atividades econômicas praticamente caracterizadas pelo extrativismo vegetal e mineral sem um processo de inovação industrial.

Na Amazônia e no Tocantins temos a fronteira agrícola nos moldes capitalista em que no seu interior contém os ingredientes do agronegócio. A fronteira agrícola mecanizada (capitalista) caracteriza-se pela incorporação de equipamentos industriais como máquinas, colheitadeiras, plantadeiras, aviões para borrifar a plantação, o uso de agrotóxicos e fertilizantes. Neste momento de ocupação do espaço, temos uma ocupação meramente econômica totalmente voltada para criação de commodities e não mais uma preocupação com a ocupação demográfica da fronteira. Mas as contradições sociais e internas do capitalismo neste espaço continuam. É o espaço do conflito entre fazendeiros, indígenas, ribeirinho, camponeses e quilombolas e, da concentração fundiária e de renda. Tem um agravante que talvez não tínhamos na frente pioneira, a utilização de agrotóxicos muito agressivos ao meio ambiente e aos recursos hídricos.

Este espaço de conflitos contraditórios é algo que sua concretização não acontece por acaso, pelo contrário, a fronteira se estabelece a partir do planejamento político e econômico do Estado. Para que haja a expansão geográfica do modo de produção capitalista do centro para a periferia, é necessário que haja o empenho do Estado através 
de suas políticas de investimento e aquilo que seus defensores chamam de desenvolvimento, progresso. No próximo tópico, analisaremos este empenho do Estado na formação da fronteira a partir dos programas de investimentos regionais e dos eixos de (des)envolvimento regional.

\section{Eixos de (des)envolvimento regional e programas de investimentos}

Durante o regime militar no período de 1964 a 1985, o Brasil vivenciou uma série de estratégias governamentais voltadas à integração nacional e a extração de recursos naturais. Estas estratégias resultaram na exploração desenfreada de minérios na Amazônia e a associação entre a burguesia nacional, o Estado e grupos estrangeiros. Nesse período, o governo brasileiro propagava um ideal nacionalista de defesa à integração nacional com o intuito de proteger o Brasil de invasão de países estrangeiros, especialmente aqueles que fazem fronteira com a Amazônia.

A política de "Integrar para não Entregar", na verdade, encobria intenções contrárias, isto é, as intenções eram o combate aos ideais socialistas no país. Este combate do governo brasileiro na Amazônia começou através da SUDAM (Superintendência de Desenvolvimento da Amazônia), um dos maiores projetos de ocupação e exploração de recursos minerais que já ocorreu na Amazônia, inclusive por grupos estrangeiros que emprestaram capital ao Brasil. Os juros foram pagos com minérios, principalmente ferro e manganês. Para Oliveira (1991), é nesse momento em que a lógica do grande monopólio estrangeiro se torna mais nítida: emprestam-se dólares do exterior e, para efetuar o pagamento do juro, são exportados os recursos minerais.

A partir do projeto de integração nacional, com o financiamento do capital estrangeiro, iniciam-se obras de infraestrutura, como a abertura de estradas, a exemplo da rodovia Transamazônica e Belém-Brasília, cujo objetivo era possibilitar o acesso da população nordestina e empresários agropecuaristas ao interior da Amazônia. O governo brasileiro tinha o objetivo de colocar em prática a exploração econômica da Região Norte e estimulou não só a extração de recursos minerais, como também de madeira, além da expansão da atividade agropecuária em áreas de terra firme. Enquanto era financiado pelo capital estrangeiro, o Estado dava como garantia a apropriação desse território, um investimento sem riscos para os empresários que desejassem avançar nessa frente pioneira de ocupação. 
O POLAMAZÔNIA criado no governo militar, teve o objetivo de promover a exploração da Amazônia pelas atividades agropecuárias, agroindustriais e florestais nas regiões de Xingu-Araguaia, Carajás, Araguaia-Tocantins, Trombetas, Altamira, PréAmazônia Maranhense, Rondônia, Acre, Juruá-Solimões, Roraima, Tapajós, Amapá, Juruena, Aripuanã e Marajó, com a finalidade de explorar minérios e madeira.

Tornou-se vantajoso para bancos, companhias de seguro, mineradoras e empresas estatais, de transportes ou de construção de estradas investir na devastação da floresta tropical para introduzir grandes projetos de criação de gado, com subsídios oficiais, realizando a exploração das terras a preços baixos. (KOHLHEPP, 2002, p. 06)

Os objetivos do POLAMAZÔNIA não obtiveram o êxito esperado, excetuandose os investidores estrangeiros que em muito se beneficiaram com a exploração e exportação de minérios brasileiros, mas as obras de construção das estradas que cruzam o Brasil, no sentido Nordeste/Norte, em sua maioria não foram concluídas, a exemplo da rodovia Transamazônica.

O POLOCENTRO também criado no governo militar, cuja proposta estava voltada a exploração do cerrado, principalmente, o goiano e o mato-grossense. Ele objetivava a ocupação do cerrado pela soja, a fim de diminuir as tensões existentes no sul do Brasil, onde era muito cultivada. As metas a serem alcançadas pelo POLOCENTRO tiveram melhor êxito para o capital. Entretanto, a partir da implantação deste programa, a soja entre outras monoculturas de grãos está comprometendo a biodiversidade do cerrado, e expulsando a população camponesa de suas terras, através do processo de concentração de terras pelos grandes latifúndios.

Segundo Cerqueira (2016), no final da década de 1970 foi criado outro Programa Nacional de Desenvolvimento, o POLONOROESTE. Esse programa teve como objetivo a colonização agrícola de terras em Rondônia e Mato Grosso, através do financiamento do Banco Mundial e, procurou, além da abertura/pavimentação de rodovias, alimentar programas de colonização em Rondônia e de (des)envolvimento e regularização fundiária em Mato Grosso. A regularização fundiária teve o objetivo de legalizar as terras griladas.

Além dos programas citados, o cerrado Brasileiro foi alvo de outro programa de cooperação entre o Brasil e o Japão, conhecido como PRODECER. O objetivo desse programa implementado no final da década de 1970, era a produção de commodities para o mercado estrangeiro. Foi implantado em três fases: a primeira no estado de Minas 
Gerais, a seguinte em Goiás, Mato Grosso, Mato Grosso do Sul e Bahia, e a última, na década de 1990 atingiu o Tocantins e o Maranhão.

Para o (des)envolvimento regional da Amazônia, além de programas de (des)envolvimento já descritos, o Estado fomentou implantação de eixos de (des)envolvimento para favorecer a expansão do capital agropecuário. Dentro do projeto de integração nacional pensado por Vargas e concretizado no governo de Juscelino Kubitschek, foi construída a rodovia BR-153, conhecida como Belém-Brasília, que cruza o estado do Tocantins de norte a sul como podemos observar no Mapa $\mathrm{n}^{\circ} 01$ a seguir. $\mathrm{O}$ mapa apresenta um número significativo de cidades em suas margens, o que demonstra a importância da rodovia no processo de urbanização do Tocantins. O objetivo dessa rodovia era integrar o Meio-Norte ao Centro-Sul do Brasil, tornando-a a principal via de escoamento da produção e acesso aos estados do Tocantins e Goiás. Como ressalta Souza (2002, p. 353) "através da política desenvolvimentista, a expansão rodoviária era vista como uma forma de integrar geográfica e economicamente as várias regiões do país".

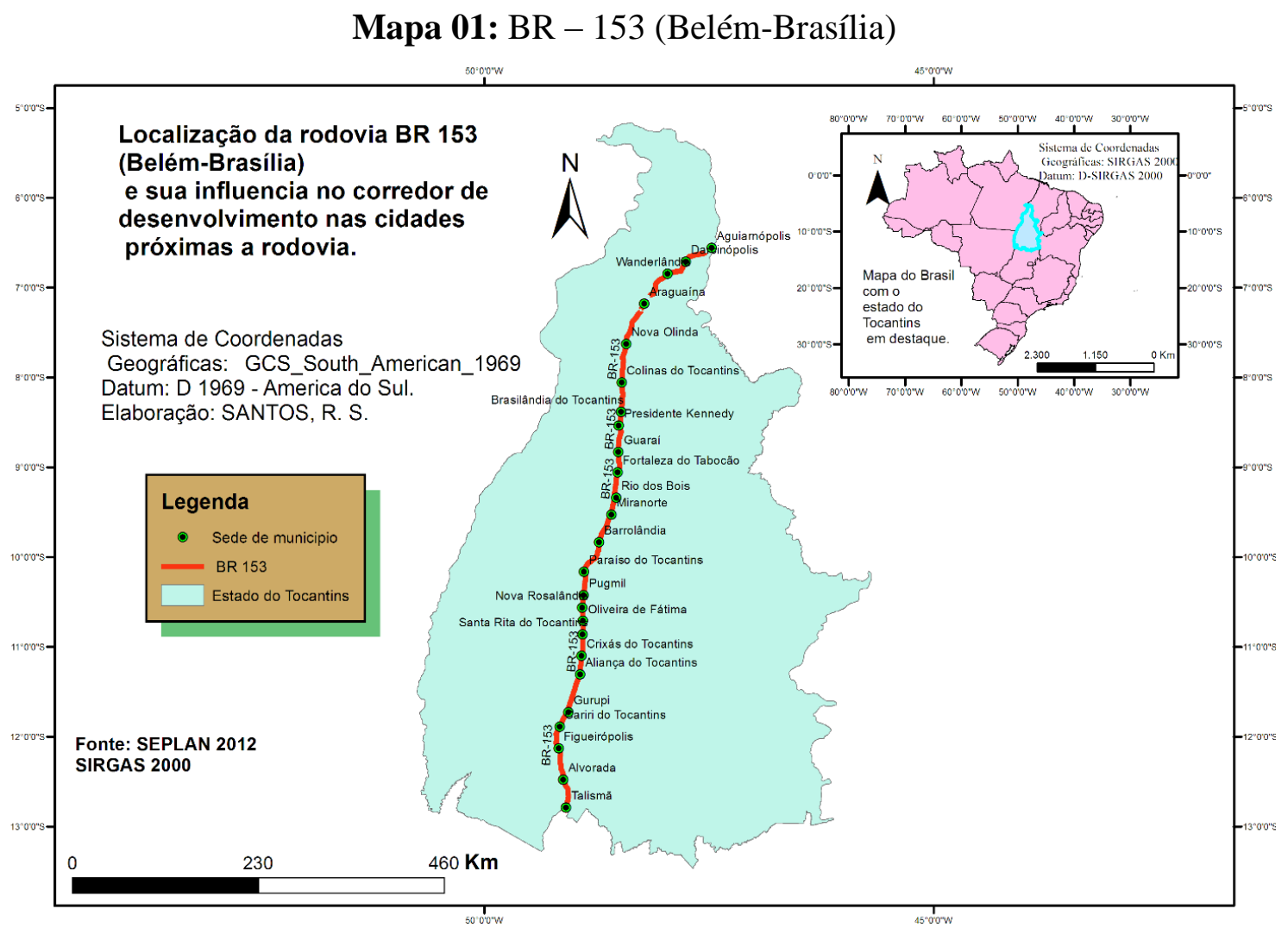

Na Amazônia, além da perda de uma parte significativa da Floresta Amazônica, pelo desmatamento, queimadas e pela ocupação desordenada, a população ainda 
permanece no isolamento, a exemplo, dos pequenos aglomerados urbanos que se formaram a partir da abertura de estradas como a Transamazônica, ainda inacabada. No Tocantins, a construção da rodovia BR-153, a principal via de escoamento da produção agrícola, não foi capaz de integrar todo o estado ao restante do Brasil, a exemplo da região do Jalapão. Como ressalta Lira (2011, p. 152):

Concluímos que, nem a hidrovia do Tocantins e muito menos a Belém-Brasília, foram suficientes para fazer a integração da região. A hidrovia esbarrou na sazonalidade da navegação, a Belém-Brasília deslocou o eixo um pouco para a esquerda, sem se integrar à região.

Outro eixo de integração regional é a ferrovia Norte-Sul, que tem como objetivo escoar a produção do cerrado para o Porto de Itaqui no Maranhão. Santos (2013), ressalta que o principal objetivo da ferrovia é a ampliação das atividades do agronegócio. Será mais uma via de escoamento da produção de grãos para o mercado externo. A ferrovia Norte-Sul se estende pelo país da Região Sul a Região Norte, e no Tocantins, está paralela a rodovia BR-153 no Tocantins. A ferrovia em toda a sua extensão tem vários pátios multimodais como o de Porto Nacional/Palmas, Aguiarnópolis, Araguaína, Colinas, Guaraí e Gurupi, como ilustra o Mapa n 2. Em outras palavras, podemos afirmar que a ferrovia Norte-Sul constitui um eixo de (des)envolvimento para estimular o crescimento e (des)envolvimento regional no país. No Tocantins, esta ferrovia favoreceu a ampliação da atividade econômica do agronegócio. Pelo Mapa 02, ainda é possível observar a influência da ferrovia no processo de urbanização da região. Lembrando que várias cidades que ficam nas imediações da ferrovia já existiam antes de sua implantação.

Entre os objetivos da criação dessa ferrovia, está presente o estímulo ao desenvolvimento econômico e integração territorial da malha viária intermodal nacional. Ampliar o escoamento de matéria-prima para os portos do Norte brasileiro e fomentar o desenvolvimento regional. O agronegócio será uma das atividades econômicas que se beneficiará de forma significativa no quesito de transporte e escoamento de grãos para a exportação. (SANTOS, 2013, p. 146)

Para o referido autor, a geografia dos transportes na fronteira sudeste da Amazônia ficará mais completa com a construção da Ferrovia de Integração Oeste-Leste, também referida como Leste-Oeste. A sua construção está nos planos do governo federal. Ela passará pelos estados da Bahia e do Tocantins, ligando as cidades de Ilhéus (BA) e Figueirópolis (TO). Nesse trecho é onde ela se conectará com a Ferrovia Norte-Sul. Essa 
conexão elevará a logística no sudeste da Amazônia de forma satisfatória para o crescimento econômico da região, claro, e este projeto for concretizado.

Mapa 02: Ferrovia Norte-Sul no Tocantins

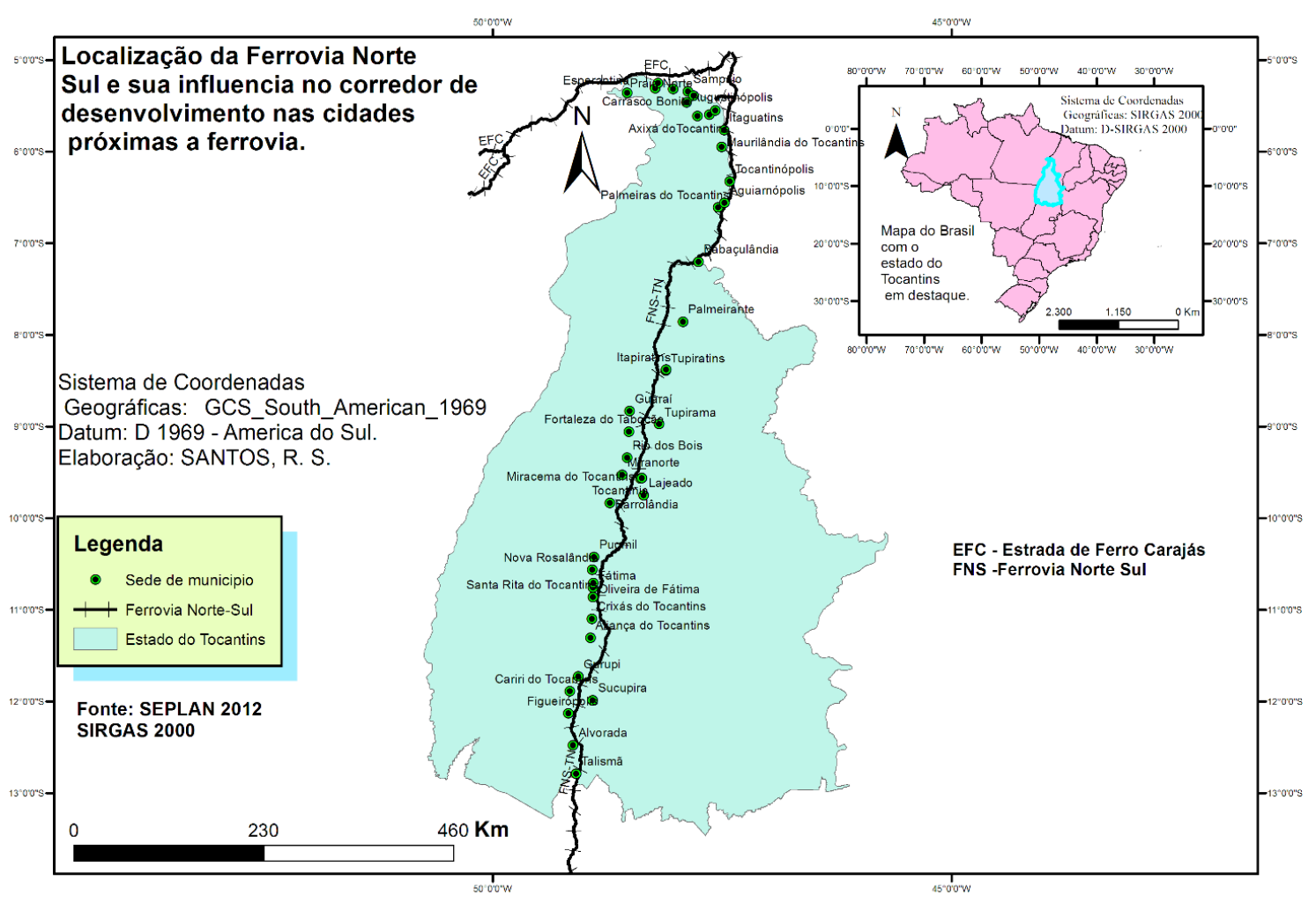

Como vimos nos tópicos descritos acima, a formação da fronteira capitalista é conduzida estrategicamente pelo Estado para atender os interesses do capital agropecuário. Lembrando que o capital, no caso, agronegócio, procura novas fronteiras de forma seletiva, ou seja, escolhe aqueles espaços estratégicos que permita a sua reprodução. No próximo tópico, descrevemos os municípios que se tornaram espaços estratégicos do agronegócio no Tocantins.

\section{Descrição dos municípios considerados estratégicos pelo agronegócio no Tocantins}

Em Tocantins existe um interesse do governo estadual em definir onde se instalarão a atividade econômica do agronegócio nos municípios. Isso é reforçado pelo discurso de (des)envolvimento propagado pelo Estado e pelos promotores do agronegócio que enfatizam a ideia de que a atividade econômica do agronegócio traz a prosperidade e crescimento econômico e cria melhores condições sociais. A exemplo desses municípios, 
temos Campos Lindos, Formoso do Araguaia, Lagoa da Confusão, Porto Nacional e Pedro Afonso que examinaremos a seguir. O Mapa 03 a seguir, ilustra a localização dos municípios analisados. Observando o Mapa 03, os municípios analisados estão muitos dispersos espacialmente no estado do Tocantins, não representando uma contiguidade espacial entre eles. A escolha destes municípios dispersos como amostragem, se justifica pelo fato deles representarem os municípios com a atividade econômica do agronegócio mais dinâmica e atuante do Tocantins.

Mapa 03: Localização dos municípios analisados

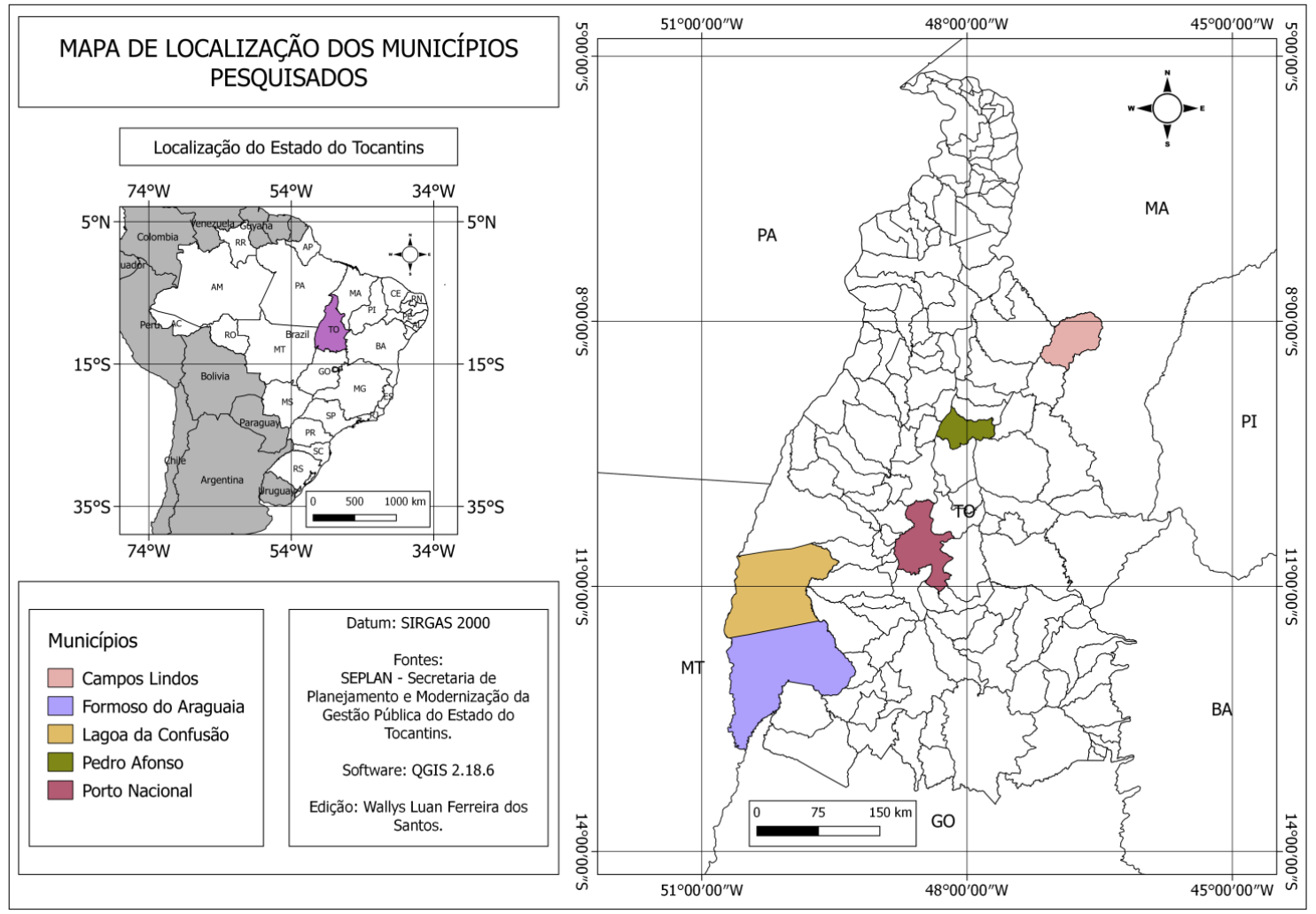

O município de Campos Lindos uma das áreas estratégicas do agronegócio está localizado a $491 \mathrm{~km}$ da capital Palmas, na microrregião do Jalapão, possui uma área de $3.240,18 \mathrm{~km}^{2}$ e uma população estimada em 10.116 em 2019 (IBGE, 2019). A base de sua economia é a atividade agropecuária, destacando-se a produção de soja. A criação do município foi uma estratégia do governador Siqueira Campos com o objetivo de servir à produção agropecuária, devido à potencialidade de seus solos. O município é um exemplo de expansão da produção agrícola a partir da década de 1990. 
Formoso do Araguaia é remanescente de um povoado que surgiu no final da década de 1940, sendo desmembrado do município de Cristalândia em 1963. O município conta com uma área de 13.423,38 km² e uma população estimada em 18.440 em 2019 (IBGE, 2019). É um município que o agronegócio está presente. Em 1979, o município foi contemplado pelo Projeto Rio Formoso de agricultura irrigada que é a sua principal atividade econômica. Ao governo de Goiás competiu à elaboração de estudos sobre a região, o apoio técnico e o financiamento do projeto, o que atraiu investidores de outras regiões.

Segundo Barbosa (1996), para a implantação do projeto, o governo desapropriou uma área e criou 3 cooperativas: Coopergran, Cooperformoso e Cooperjava. As terras foram desapropriadas de proprietários particulares, o que não enquadrou em terras devolutas da União. Estas terras desapropriadas foram repassadas as cooperativas, na forma de arrendamento. Segundo Barbosa (1996, p. 10), foi um arredamento muito generoso que uma saca de arroz pagaria por um ano. As cooperativas tiveram a renda da terra sem imobilizar capital. Com a divisão do estado de Goiás, em que criou o estado do Tocantins, a União absorveu as dívidas das cooperativas. O projeto beneficiou diretamente alguns empresários, amigos e parentes do governador Ary Valadão. Em contrapartida, o projeto não incorporou o camponês da região.

O povoado que deu origem ao município de Lagoa da Confusão teve início em 1941, mas somente em 1991 foi desmembrado do município de Cristalândia. Sua população é estimada em 13.357 em 2019 (IBGE, 2019). Sua principal atividade econômica é a agropecuária, destacando-se a produção de arroz e a criação de bovinos. Devido a essa atividade, o município de Lagoa da Confusão está entre os onze maiores PIB's do estado do Tocantins (SEPLAN, 2013). A região de Lagoa da Confusão pelo fato de compor a região do médio Araguaia teve a sua produção voltada também à produção de grãos de forma irrigada. As áreas de várzeas e ipucas no entorno da Ilha do Bananal são um grande atrativo à produção de grãos e ao desenvolvimento da pecuária. Segundo Martins, et ali (2002), são fragmentos florestais naturais, denominados regionalmente de ipucas, localizado no município de Lagoa da Confusão-TO, que ocorrem em meio ao cerrado central, às margens do rio Araguaia e na Ilha do Bananal. A fragmentação é resultante de remanescentes de vegetação nativa. Esses fragmentos ficam alagados em até três metros por seis meses do ano. 
Atualmente, há o projeto PRODOESTE voltado para a produção agrícola irrigada com o objetivo de estimular o agronegócio no município. Para expansão da produção agrícola, a construção de obras como uma barragem de acumulação no Rio Pium e quatro barragens elevatórias de nível nos rios Pium e Riozinho, construção e melhorias das estradas vicinais, serão necessárias. A elaboração do Programa de Desenvolvimento da Região Sudoeste do Estado do Tocantins (PRODOESTE) reflete a intenção do governo estadual em incentivar o (des)envolvimento de um polo de produção hidro-agrícola e agroindustrial na região, em função do potencial dos solos, da disponibilidade de recursos hídricos e da prática da agricultura irrigada.

O município de Pedro Afonso abrange uma área de 2.010,90 km², com uma população estimada em 13.578 em 2019 (IBGE, 2019). É um dos municípios mais antigos do estado do Tocantins, seu povoamento data de 1845, elevado à condição de distrito em 1875, e emancipado em 1938. Em 2010, o município teve um grande destaque quanto à produção agropecuária, dando destaque à soja, à cana-de-açúcar e ao arroz (SEPLAN, 2013). É o município onde o governo federal implantou o PRODECER III. O PRODECER representa a terceira fase que em meados da década de 1990, os municípios de Pedro Afonso (TO) e Balsas (MA) foram beneficiados pelo financiamento dos custos operacionais para a produção de grãos, principalmente a soja.

O PRODECER III foi idealizado em 1974 e negociado entre os governos brasileiro e japonês durante cinco anos e implementado a partir do ano de 1978. O principal instrumento do programa é o crédito supervisionado, com linhas de financiamento abrangentes e empréstimos fundiários para investimentos, despesas operacionais e assistência ao colono. Este projeto resultou da assinatura de convênio com o Japão, em 1976, que propôs-se financiar a ocupação do cerrado e desenvolver uma área agrícola de cerca de $500.000 \mathrm{~km}^{2}$ para o incentivo de uma agricultura de exportação, obviamente, para atender às necessidades do mercado consumidor japonês (PESSÔA; SANCHES, 1989). A terceira etapa (PRODECER III) do Programa teve início em 1996, implantado nos municípios de Pedro Afonso (TO) no Nordeste do Tocantins e Balsas (MA) no Sul do Maranhão. Como nas outras fases, a gestão do projeto coube à Companhia de Promoção Agrícola (CAMPO), empresa joint venture que associa a participação brasileira e japonesa, criada com a função específica de coordenar e administrar o PRODECER, afirma Pires (1996, p. 70). 
Este programa abriu espaço para o agronegócio. Pelo fato de ter sido incorporado na terceira fase do programa nipo-brasileiro, denominado PRODECER III, o município de Pedro Afonso se tornou atrativo à produção de grãos. Em uma área de 40 mil hectares é a continuação da frente de expansão da agricultura moderna no cerrado, iniciada pelos governos militares no cerrado mineiro, capitalizada pelo JICA - uma empresa de capital nipo/brasileiro.

O PRODECER foi um dos projetos da política nacional de (des)envolvimento, voltado diretamente ao (des)envolvimento regional do cerrado, que proporcionou resultados positivos à aristocracia do agronegócio. Projetado para desenvolver o potencial agrícola do cerrado, esse programa, sob a supervisão de parceiros japoneses, selecionou as áreas, os tipos de lavouras e técnicas que seriam empregadas, e o perfil dos colonos que ocupariam as terras com maior potencial para a produção.

O financiamento do PRODECER permitiu aos colonos subsidiarem a sua produção em larga escala para o mercado estrangeiro. A partir da implantação deste projeto, houve um crescimento significativo na ocupação e cultivo de soja e cana-deaçúcar no município de Pedro Afonso. Atualmente, a produção agropecuária é o carrochefe do município com destaque a produção de cana de açúcar. Com a implantação deste projeto, as terras do município de Pedro Afonso vão aparecer nas políticas de planejamento e (des)envolvimento como área de avanço tecnológico na agricultura, isto significa afirmar que as áreas destinadas à monocultura da soja, ou seja, áreas especificamente "preparadas" para investimento de capitais internacionais e nacionais com o objetivo de alavancar o processo de (des)envolvimento regional.

O município de Porto Nacional tem uma população estimada da ordem de 53.010 em 2019 (IBGE, 2019). A sua área é de 4.449,92 km² e está localizado na região central do estado do Tocantins. A ocupação da região é datada de 1722, no período de exploração do ouro em Goiás. Em 1831, o julgado de Porto Real foi elevado a Porto Imperial. Após a contagem evolutiva de trinta anos da instalação de Porto Imperial, em 1861, por determinação de Resolução Provincial, nasceu Porto Nacional, importante polo cultural, político, econômico e social do então Norte Goiano, hoje estado do Tocantins (IBGE, 2010).

A ferrovia Norte-Sul que cruza o estado do Tocantins tem uma plataforma no município de Porto Nacional. A sua localização no centro do estado e o acesso à ferrovia, 
fez do município um polo atrativo para o agronegócio, que vem avançando pelo estado de Goiás para a Amazônia. Em Porto Nacional já tem várias empresas do agronegócio, entre as quais, podemos destacar a Bunge, Granol Indústria Comércio e Exportação S/A e Pioneer sementes.

\section{Atividade econômica do agronegócio e (des)envolvimento regional e humano}

O (des)envolvimento do agronegócio na região é resultado das ações políticas do Estado que oferece as condições para que o capital se instale. É o Estado quem promove toda a infraestrutura necessária para a expansão do capital, mesmo com o sério comprometimento dos recursos naturais e os impactos nos territórios das comunidades tradicionais. A partir da chegada do capital do agronegócio ao Tocantins, é possível constatar que as condições econômica e social da população, não é proporcional ao crescimento econômico criado pelo agronegócio. Ainda é possível observar que boa parte da população camponesa expulsa do campo para os pequenos centros urbanos, teve uma perda significativa quanto à qualidade de vida social e econômica. Pois, no mínimo, ficaram sem acesso à terra que produzia a renda necessária ao provimento de suas despesas e demandas.

É importante compreender que o discurso do "Progresso e Desenvolvimento" propagado pelo Estado e pelo capital, é falacioso. A partir deste raciocínio, podemos fazer o seguinte questionamento: até que ponto há de fato uma melhoria de qualidade de vida, social e econômica da população nos municípios impactados diretamente pelo crescimento econômico do agronegócio. O discurso mais propagado desde o período da ditadura militar no Brasil é o da chegada do "desenvolvimento e do progresso". Como se todos os impactos negativos pudessem ser ignorados em detrimento dos benefícios advindos dos setores que movem a economia. Estas questões serão debatidas a seguir.

É possível observar que o PIB per capita dos municípios de Campos Lindos, Formoso do Araguaia, Lagoa da Confusão, Pedro Afonso e Porto Nacional têm crescido nos últimos anos, devido à produção de soja, entre outros grãos. Como pode-se observar no Quadro 1, que em um período de 12 anos, o PIB per capita destes municípios mais que triplicou, destacando-se Campos Lindos, Lagoa da Confusão, Pedro Afonso e Porto Nacional por apresentarem os aumentos mais expressivos no período entre 2002 e 2014. O maior destaque foi para o município de Pedro Afonso no período analisado. Vale 
lembrar que o PIB per capita municipal representa uma média da produção anual e não significa exatamente uma distribuição de renda na vida real de cada habitante do município.

Quadro 1: PIB per capita, segundo municípios - Tocantins 2002-2014

\begin{tabular}{|l|c|c|c|}
\hline \multirow{2}{*}{ Municípios } & PIB per capita (R\$) & PIB per capita (R\$) & PIB per capita $(\mathbf{R} \$)$ \\
\cline { 2 - 4 } & 2002 & 2008 & 2014 \\
\hline Campos Lindos & 6.131 & 16.137 & 34.868 \\
\hline Formoso do Araguaia & 5.695 & 8.659 & 17.304 \\
\hline Lagoa da Confusão & 6.854 & 16.268 & 36.542 \\
\hline Pedro Afonso & 6.551 & 13.235 & 55.240 \\
\hline Porto Nacional & 4.369 & 8.608 & 21.618 \\
\hline
\end{tabular}

Fonte: SEPLAN-TO, Diretoria de Pesquisa, 2014. Organizado pelo o autor.

A produção agropecuária é uma das principais atividades econômicas do estado do Tocantins. Ela está presente em todos os municípios do estado, seja na produção de grãos ou na criação de gado. Nos municípios escolhidos pelo agronegócio são desenvolvidas as duas atividades, que juntas contribuem para a elevação do índice do PIB estadual. No Quadro 2, podemos visualizar o rendimento obtido com a atividade agropecuária (grãos e criação de gado), a arrecadação em impostos sobre essas atividades e outras como indústria e comércio, o PIB municipal e a classificação do PIB estadual dos municípios analisados.

Entre os municípios analisados, Porto Nacional apresenta a melhor classificação do PIB ao nível estadual em 2010, ocupando a $5^{\text {a }}$ posição. Nos municípios de Campos Lindos, Formoso do Araguaia e Lagoa da Confusão, a atividade agropecuária representa um valor considerável para compor o valor do Produto Interno Bruto, o que demonstra a força dessa atividade no estado do Tocantins, onde a atividade industrial ainda é incipiente. No ranking estadual, Porto Nacional e Formoso do Araguaia são os primeiros colocados na classificação do PIB municipal entre os municípios listados para o ano de 2010, conforme ilustra o Quadro 02.

Quadro 2: Produto Interno Bruto a preços correntes, classificação, valor adicionado (va) por setor, e impostos, segundo municípios - Tocantins - 2010

\begin{tabular}{|l|c|c|c|c|}
\hline Municípios & $\begin{array}{c}\text { Agropecuária } \\
(\mathbf{1 0 0 0} \mathbf{R} \mathbf{)}\end{array}$ & $\begin{array}{c}\text { Impostos } \\
(\mathbf{1 0 0 0} \mathbf{R} \mathbf{)})\end{array}$ & $\begin{array}{c}\text { PIB (1000 } \\
\mathbf{R} \mathbf{\$})\end{array}$ & $\begin{array}{c}\text { Classificação PIB } \\
\text { estadual }\end{array}$ \\
\hline Campos Lindos & 68.589 & 14.930 & 161.233 & $17^{\mathrm{a}}$ \\
\hline Formoso do Araguaia & 68.198 & 13.257 & 214.558 & $12^{\mathrm{a}}$ \\
\hline Lagoa da Confusão & 78.124 & 8.794 & 170.220 & $16^{\mathrm{a}}$ \\
\hline Pedro Afonso & 43.755 & 17.311 & 175.468 & $15^{\mathrm{a}}$ \\
\hline Porto Nacional & 35.286 & 71.935 & 550.115 & $05^{\mathrm{a}}$ \\
\hline
\end{tabular}

Fonte: IBGE/SEPLAN-TO, Diretoria de Pesquisa, 2010. Organizado pelo autor. 

espaço do agronegócio no Tocantins

Outros índices que devem ser observados, referem-se ao IDH (Índice de Desenvolvimento Humano). Os municípios de Pedro Afonso e Porto Nacional são os que possuem o melhor IDH dentre os cinco analisados para o ano de 2010 (Quadro 03), e estão entre os dez melhores no ranking estadual, sendo superados apenas pelos municípios de Palmas, Paraíso do Tocantins, Gurupi, Araguaína e Guaraí. O município de Campos Lindos possui o segundo pior índice de IDH no ranking estadual $\left(138^{\circ}\right)$ ficando à frente apenas do município de Recursolândia em um total de 139 municípios. A colocação de Campos Lindos na posição $138^{a}$ no ranking estadual é uma tese que deixa evidente que o agronegócio não possibilitou a elevação dos indicadores sociais no município e, não foi capaz de superar o ranking dos 137 municípios do estado. Observando o Quadro 3, podemos perceber que o município de Campos Lindos teve a maior taxa de crescimento do IDH na ordem de 58,60\% entre 2000 e 2010. Entretanto, com esse aumento não foi capaz de acompanhar os demais municípios.

Quadro 3: População, IDH, taxa de crescimento e ranking estadual - 2010

\begin{tabular}{|l|c|c|c|c|c|}
\hline \multirow{2}{*}{ Municípios } & Popul. censo & IDH & IDH & $\begin{array}{c}\text { Taxa de crescimento } \\
(\%) \text { do IDH }\end{array}$ & $\begin{array}{c}\text { Ranking } \\
\text { estadual }\end{array}$ \\
\cline { 2 - 6 } & 2010 & 2000 & 2010 & & $(2010)$ \\
\hline Porto Nacional & 49.146 & 0,562 & 0,740 & 31,67 & $6^{\mathbf{o}}$ \\
\hline Pedro Afonso & 11.539 & 0,546 & 0,732 & 34,07 & $7^{\mathrm{a}}$ \\
\hline Formoso do Araguaia & 18.427 & 0,507 & 0,670 & 32,15 & $34^{\mathrm{a}}$ \\
\hline Lagoa da Confusão & 10.210 & 0,479 & 0,627 & 30,90 & $82^{\mathrm{a}}$ \\
\hline Campos Lindos & 8.139 & 0,343 & 0,544 & 58,60 & $138^{\mathrm{a}}$ \\
\hline
\end{tabular}

Fonte: Atlas 2013 - PNUD. Organizado pelo autor.

No quesito IDH educação, Campos Lindos teve um aumento significativo, passou de 0,126 para 0,377 no período de 2000 e 2010, conforme ilustra o Quadro 4.

Quadro 4: Índice de desenvolvimento humano municipal e seus componentes - 2000

\begin{tabular}{|l|c|c|c|}
\hline Municípios & IDH Educação & IDH Longevidade & IDH renda \\
\hline Porto Nacional & 0,406 & 0,708 & 0,619 \\
\hline Pedro Afonso & 0,376 & 0,730 & 0,592 \\
\hline Formoso do Araguaia & 0,326 & 0,669 & 0,599 \\
\hline Lagoa da Confusão & 0,281 & 0,659 & 0,595 \\
\hline Campos Lindos & 0,126 & 0,607 & 0,527 \\
\hline \multicolumn{2}{|c|}{ Índice de desenvolvimento humano municipal e seus componentes - 2010 } \\
\hline Municípios & IDH Educação & IDH Longevidade & IDH Renda \\
\hline Porto Nacional & 0,701 & 0,826 & 0,699 \\
\hline Pedro Afonso & 0,664 & 0,846 & 0,699 \\
\hline Formoso do Araguaia & 0,587 & 0,801 & 0,640 \\
\hline Lagoa da Confusão & 0,496 & 0,787 & 0,630 \\
\hline Campos Lindos & 0,377 & 0,738 & 0,578 \\
\hline
\end{tabular}

Fonte: Atlas 2013 - PNUD. Organizado pelo autor. 
No Quadro 04, podemos perceber que o município de Campos Lindos tem o pior desempenho dos indicadores sociais entre os municípios analisados, tanto no IDH educação, longevidade e renda para o ano de 2000 como para o ano de 2010, conforme podemos visualizar no Quadro 4. Lembrando que o município de Campos Lindos é um dos maiores exportadores de commodities agrícola do estado.

Observando o Quadro 05, podemos perceber que só o município de Campos Lindos aumentou o percentual dos ocupados com rendimentos até 2 salário mínimos entre 2000 e 2010. Os outros municípios acompanham a dinâmica nacional, isto é, tiveram uma diminuição desse percentual entre 2000 e 2010. No quesito de percentual dos ocupados sem rendimento com 18 anos ou mais, o município de Lagoa da Confusão tinha maior percentual em 2000, cerca de $18,17 \%$ e caiu para 5,15\% em 2010. Campos Lindos apresentou o maior percentual neste quesito cerca de 23,36\% no ano de 2010. Porto Nacional pelo contrário dos outros municípios, aumentou o percentual de 4,76\% para $5,87 \%$ no período de 2000 a 2010. De uma maneira geral, houve uma queda do percentual dos ocupados sem rendimento dos municípios acompanhando a dinâmica estadual e nacional no período de 2000 a 2010.

Quadro 5: Percentual dos ocupados sem rendimento e dos ocupados com rendimento de até 2 salários mínimos 18 anos ou mais

\begin{tabular}{|l|c|c|c|c|}
\hline & \multicolumn{1}{|c|}{ Ano de 2000 } & Ano de 2010 & \multicolumn{1}{c|}{ Ano de 2000 } & \multicolumn{1}{c|}{ Ano de 2010 } \\
\cline { 2 - 5 } Municípios & $\begin{array}{l}\text { \% dos ocupados } \\
\text { sem rendimento } \\
18 \text { anos ou mais }\end{array}$ & $\begin{array}{l}\text { \% dos } \\
\text { ocupados sem } \\
\text { rendimento 18 } \\
\text { anos ou mais }\end{array}$ & $\begin{array}{l}\text { \% dos ocupados } \\
\text { com rendimento de } \\
\text { até 2 salários } \\
\text { mínimos 18 anos ou } \\
\text { mais }\end{array}$ & $\begin{array}{l}\text { \% dos ocupados } \\
\text { com rendimento de } \\
\text { até 2 salários } \\
\text { mínimos 18 anos ou } \\
\text { mais }\end{array}$ \\
\hline Brasil & $\mathbf{6 , 1 5}$ & $\mathbf{5 , 5 8}$ & $\mathbf{7 2 , 4 8}$ & $\mathbf{6 9 , 5 6}$ \\
\hline Tocantins & 10,85 & 8,84 & 83,69 & 73,94 \\
\hline Campos Lindos & - & 23,36 & 85,72 & 88,16 \\
\hline $\begin{array}{l}\text { Formoso } \\
\text { Araguaia }\end{array}$ & 10,38 & 8,92 & 83,93 & 79,85 \\
\hline Lagoa da Confusão & 18,17 & 5,15 & 86,15 & 80,7 \\
\hline Pedro Afonso & 6,80 & 4,34 & 83,80 & 66,91 \\
\hline Porto Nacional & 4,76 & 5,87 & 80,38 & 73,33 \\
\hline
\end{tabular}

Fonte: Atlas de Desenvolvimento Humano - PNUD, 2013. Organizado pelo autor.

Para mensurar a renda, usa-se o Índice de Gini que foi criado pelo matemático italiano Conrado Gini, é um instrumento para medir o grau de concentração de renda em determinado grupo. No que se refere ao índice de Gini que representa a desigualdade social, o município de Campos Lindos tem o maior índice do que os demais municípios listados, inclusive maiores do que o estadual e nacional entre 2000 e 2010, conforme 
ilustra o Quadro 6. No período de 1991 a 2010, os municípios de Campos Lindos e Lagoa da Confusão aumentaram o índice de desigualdade social, indo na contramão dos demais, inclusive para o patamar estadual e nacional. Pedro Afonso detém o menor índice de Gini para o ano de 2010, conforme demonstra o Quadro 07. Dentre os municípios listados, Campos Lindos apresenta maior desigualdade social.

Quadro 6: Índice de Gini
\begin{tabular}{|l|c|c|c|}
\hline Municípios & Ano de 1991 & Ano de 2000 & Ano de 2010 \\
\hline Brasil & $\mathbf{0 , 6 3}$ & $\mathbf{0 , 6 4}$ & $\mathbf{0 , 6 0}$ \\
\hline Tocantins & 0,63 & 0,65 & 0,60 \\
\hline Campos Lindos & 0,56 & 0,70 & 0,67 \\
\hline Formoso do Araguaia & 0,56 & 0,61 & 0,52 \\
\hline Lagoa da Confusão & 0,49 & 0,66 & 0,51 \\
\hline Pedro Afonso & 0,57 & 0,59 & 0,50 \\
\hline Porto Nacional & 0,58 & 0,60 & 0,54 \\
\hline
\end{tabular}

Fonte: Atlas de Desenvolvimento Humano - PNUD, 2013. Organizado pelo autor.

Observando do Quadro 07, podemos perceber que os municípios de Campo Lindos $(27,27 \%)$ e Pedro Afonso (29,80\%) detêm o menor percentual no quesito grau de formalização dos ocupados para o ano de 2000. Isso significa dizer que estes municípios têm maior percentual de ocupados não formalizados. O município de Lagoa da Confusão na contramão dos demais municípios e dos patamares estadual e nacional no período de 2000 a 2010, o grau de formalização dos ocupados diminuiu de 34,38\% em 2000, para 34,17 em 2010.

Quadro 7: Grau de formalização dos ocupados 18 anos ou mais e percentual dos ocupados com médio completo 18 anos

\begin{tabular}{|c|c|c|c|c|}
\hline Municípios & Ano de 2000 & Ano de 2010 & Ano de 2000 & Ano de 2010 \\
\hline & $\begin{array}{l}\text { Grau de } \\
\text { formalização } \\
\text { dos ocupados }\end{array}$ & $\begin{array}{l}\text { Grau de } \\
\text { formalização dos } \\
\text { ocupados }\end{array}$ & $\begin{array}{l}\text { \% dos ocupados } \\
\text { com médio } \\
\text { completo }\end{array}$ & $\begin{array}{l}\text { \% dos ocupados } \\
\text { com médio } \\
\text { completo }\end{array}$ \\
\hline Brasil & 51,63 & 59,32 & 30,84 & 44,91 \\
\hline Tocantins & 35,60 & 47,16 & 23,19 & 45,29 \\
\hline Campos Lindos & 27,27 & 30,60 & 11,71 & 24,62 \\
\hline Formoso do Araguaia & 30,53 & 42,50 & 19,21 & 38,03 \\
\hline Lagoa da Confusão & 34,38 & 34,17 & 18,38 & 31,44 \\
\hline Pedro Afonso & 29,80 & 57,59 & 21,84 & 52,79 \\
\hline Porto Nacional & 44,32 & 47,91 & 27,38 & 49,74 \\
\hline
\end{tabular}

Fonte: Atlas de Desenvolvimento Humano - PNUD, 2013. Organizado pelo autor.

No quesito de percentual dos ocupados com ensino médio completo, os municípios de Campos Lindos $(24,62 \%)$ e Lagoa da Confusão $(31,44 \%)$ tem o menor patamar entre os municípios listados, inclusive, para o patamar estadual e nacional para o ano de 2010. Os municípios de Pedro Afonso (52,79\%) e Porto Nacional $(49,74 \%)$ 
detêm o maior percentual dentre os municípios listados, superando inclusive, o estadual e nacional para o ano de 2010. Apesar de todos os municípios serem baseados na mesma atividade econômica do agronegócio, há grandes divergências entre eles, no que diz respeito aos índices de desenvolvimento humano, ou seja, a atividade econômica do agronegócio não permitiu a evolução destes índices, o suficiente para colocá-los no mesmo parâmetro social.

Os indicadores sociais analisados apontam que os municípios com uma economia ligada ao agronegócio, não tem um desempenho do desenvolvimento humano mais equilibrado, se analisado no conjunto. Ou seja, este raciocínio nos permite afirmar que há uma disparidade socioeconômica entre os municípios, a ponto de uns municípios registrarem um razoável desempenho dos indicadores sociais, outros não. Sabemos que o agronegócio é uma atividade econômica altamente, excludente do ponto de vista social.

Para concluir este último tópico descrito, é importante enfatizar que, para a atividade econômica do agronegócio aconteça, é necessário que haja um intervalo de tempo. Primeiro, há a formação de uma fronteira onde o Estado entra em cena para dar respaldo a expansão do capital agropecuário. Esse respaldo acontece com apoio financeiro, isenções fiscais e financiamento de infraestrutura em rodovias, ferrovias e obras de infraestrutura. Em um segundo momento, o Estado estimulou e financiou a pesquisa e desenvolvimento para o setor agropecuário através de programas de investimentos, por exemplo, o POLOCENTRO e a criação da Empraba para aprimorar técnico-cientificamente a agricultura no cerrado. E por último, chega as empresas multinacionais que atuam com a técnica biogenética e a biotecnologia representando a agricultura apelidada de agronegócio.

Todo esse processo se desenrola de forma contraditória no tempo e no espaço. Socialmente reproduz uma sociedade de classes com desigualdades sociais visíveis e economicamente, enriquece uma minoria de pessoas com grandes fortunas. A reprodução do capital do agronegócio na fronteira, necessariamente, passa pelo processo de modernização, mas reproduzindo as velhas formas de exploração como é o caso de trabalho escravo na atividade econômica do agronegócio.

Segundo Gonçalves (2019), para dar continuidade ao modelo de (des)envolvimento anterior, Fernando Henrique Cardoso em 1996 cria um programa de abrangência nacional com previsão de 42 projetos de investimento básico, com a ideia 
aparentemente nova - a de Eixos de Integração e Desenvolvimento vem comandar as políticas de caráter territorial e regional. Segundo o referido autor, esse programa tenta implementar uma verdadeira mudança no padrão de organização do espaço que dominou de 1930 até os anos 1980, quando o Estado perdeu sua capacidade de investimentos. Entretanto, a política regional baseada nos Eixos de Integração se limitou a "exportar é o que importa" que é o ponto forte dos Eixos de Integração e Desenvolvimento que, acaba sendo via de mão única e, o que a sociedade espera não vem.

Por último, tivemos as políticas de investimento em infraestrutura criado pelo governo do Partido dos Trabalhadores - o Programa de Aceleração do Crescimento que incorporou diversos projetos previstos no Programa Brasil em Ação. Como também assumiu a mesma lógica das políticas anteriores, de intervenção sobre o território a partir da estruturação de vias de penetração, visando uma inserção competitiva dos espaços regionais brasileiros nos circuitos internacionais da economia. Em resumo, as políticas públicas territoriais direcionadas para a Amazônia e Tocantins, tomam corpo a partir de 1930, quando o governo de Getúlio Vargas instituiu a política de (des)envolvimento regional denominada de Marcha para o Oeste até os anos 2000, como podemos visualizar no cronograma abaixo.

Organograma 01: Cronologia das políticas públicas na e para a Amazônia

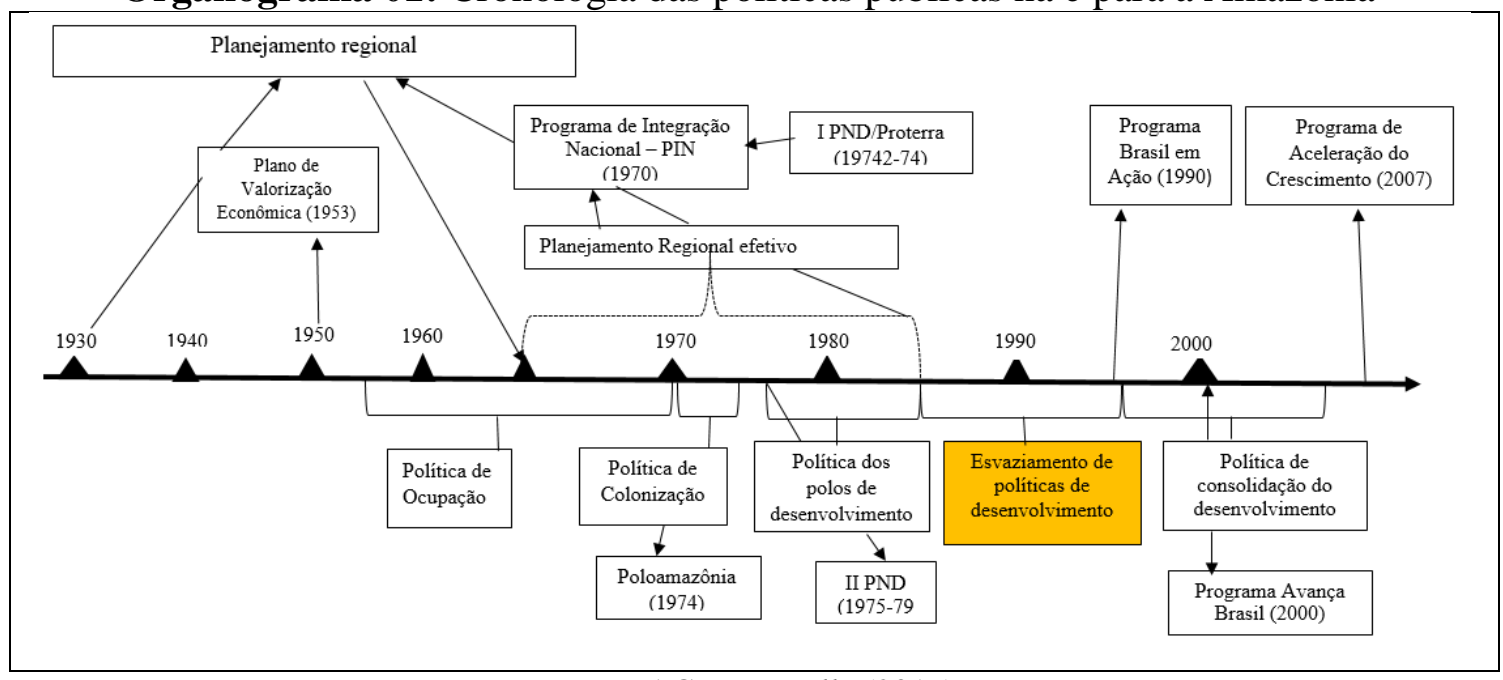

Fonte - MACIEL, et alli. (2019).

\section{Considerações finais}

Podemos constatar que a política de colonização em áreas estratégicas da Amazônia foi um instrumento em defesa da aristocracia agraria e do agronegócio. Por 
outro lado, continua reproduzindo as relações capital x trabalho do período colonial. A exemplo, na atividade econômica do agronegócio, ainda temos o trabalho escravo. Há pesquisas que confirmam esta tese, a exemplo, podemos citar o trabalho de Anatália Daiane de Oliveira, com o tema capitalismo e agronegócio aspectos do trabalho escravo no campo, publicado na Revista Direitos, Trabalho e Política Social, em 2018. A atividade do agronegócio não distribui a renda socialmente, pelo contrário, é um setor da economia que concentra a renda. $\mathrm{O}$ agronegócio gera poucos empregos, além de promover a concentração da terra e de expulsar os trabalhadores do campo. Segundo Canut (2004) as pequenas propriedades, com menos de 200 hectares, somam 3.895.968 imóveis. Elas ocupam uma área de 122.948.252 hectares e absorvem 95\% da mão-de-obra do campo e ainda assalariam 994.508 pessoas. Já as propriedades acima de 2000 hectares são só 32.264 e ocupam 132.632.500 hectares. Estas absorvem o trabalho de 45.208 pessoas $(0,3 \%)$ e assalariam outras 351.9425 . Estes dados sinalizam o quanto o agronegócio não distribui de renda e oferta poucos empregos.

O avanço do agronegócio tem acentuado o processo tanto de expropriação quanto de exploração dos trabalhadores, principalmente, com a tecnologia empregada no campo (colheitadeiras e tratores modernos equipados com GPS), que dispensam a contratação de trabalhadores. Esse processo transforma a terra de trabalho em terra de negócio. A terra de negócio é representada pela presença cada vez mais de empresas de grande porte (as multinacionais) no campo. A inserção do Brasil na divisão internacional do trabalho como exportador de produtos, aprofundou o processo de "commoditização", via exportações de produtos primários, inclusive, nos últimos tempos, há uma tendência à reprimarização da pauta exportadora do país. Isso nos induz a afirmar que o agronegócio não gera riqueza para o país, e sim para os seus detentores, pois, a venda de produtos primários não é a mesma coisa de quem vende produtos industrializados (royalties).

O Estado teve presença inquestionável na atuação do provimento e na estruturação da nova fronteira capitalizada - o agronegócio, através de sua política de expansão e ocupação econômica e demográfica na Amazônia. Não dando espaço para uma sobrevivência digna para os camponeses, indígenas e quilombolas da região. O que se percebe é que os setores sociais que se contrapõem ao agronegócio aparecem como sendo inimigos do desenvolvimento socioeconômico do Brasil. 
Os impactos negativos provenientes do agronegócio são de grandes proporções. A grande concentração de terras para a produção de monoculturas como a soja acaba apropriando dos espaços produtivos dos pequenos proprietários de terras. Os grandes latifúndios, muito embora, concentrem uma grande área de lavoura, não empregam muitos trabalhadores, parcela da mão de obra oferecida é automatizada. O plantio e a colheita da produção são realizados de forma mecanizada e sazonal, o que exige uma mão de obra técnica, muitas vezes não absorvendo a mão de obra local. Portanto, não proporciona melhorias sociais a ponto de permitir o avanço dos indicadores sociais como se propõe. O fato é que a atividade econômica do agronegócio pode aumentar o PIB per capita municipal, regional e nacional, mas, no que diz respeito aos indicadores sociais, não é a mesma tendência.

\section{Agradecimentos}

Ao apoio financeiro do CNPq.

\section{Referências}

Atlas do desenvolvimento humano no Brasil. 2013. Disponível em: <www.pnud.org.br>. Acesso em: julho. 2014.

BARBOSA, Y. M. Conflitos sociais na fronteira Amazônica. O projeto Rio Formoso. Campinas-SP: Papirus, 1996.

BEZZI, Meri Lourdes. Região: uma (re)visão historiográfica - da gênese aos novos paradigmas. Santa Maria: Editora da UFSM, 2004.

CANUT, Antônio. Agronegócio: a modernização conservadora que gera exclusão pela produtividade. REVISTA NERA - ano 7, n. 5 - agosto/dezembro DE 2004.

CERQUEIRA, Eder da Silva. Agronegócio x desenvolvimento: espaços estratégicos do agronegócio no estado do Tocantins e o índice de desenvolvimento humano. Revista Produção Acadêmica. Vol. 2 N. 1 (JUNHO, 2016), p. 05-32.

CHRISTOFOLETTI, Antônio. A inserção da geografia física na política desenvolvimento sustentável. GEOGRAFIA, Rio Claro, 18(1):1-22, Abril 1993.

\section{FAURÉ, Yves-A., HASENCLEVER, Lia. Organizadores. Caleidoscópio do} desenvolvimento local no Brasil - diversidade das abordagens e das experiências. Rio de Janeiro: E-papers, 2007. 
GONÇALVES. Carlos Walter Porto. Amazônia, Amazônias. $3^{\text {a }}$ Ed. São Paulo: Contexto, 2019.

IBGE - Instituto de Geografia e Estatística- 2019, disponível em https://cidades.ibge.gov.br/brasil/to/campos-lindos/panorama

IBGE - Instituto de Geografia e Estatística - Censo Demográfico -2010. Disponível em: www.ibge.gov.br. Acesso em julho. 2014.

KOHLHEPP, Gerd. Amazônia Brasileira: conflitos de interesse no ordenamento territorial da Amazônia Brasileira. Revista Estudos Avançados, v. 16, n. 45, São Paulo mai/ago. 2002.

LIRA, Elizeu Ribeiro. A gênese de Palmas: a geopolítica de (re)ocupação territorial na Amazônia Legal. Goiânia: Ed. Kelps, 2011.

LISBOA, Josefa Bispo de. Desenvolvimento local como simulacro do envolvimento: o novo-velho sentido do desenvolvimento e sua funcionalidade para o sistema do capital. Terra Livre. Presidente Prudente Ano 23, v. 2, n. 29 p. 15-28 Ago-Dez/2007.

MACIEL, Franciclei Burlamaque. Et ali. Política de Desenvolvimento, ambiente e saúde na Amazônia: uma análise da região do Tapajós. Rev. Bras. Estud. Urbanos Reg. São Paulo, v.21, n.1, p.155-172, jan.-abr. 2019.

MANFRÉ, Edson Roberto. Desenvolvimento local e o arranjo produtivo local - APLs. Revista Geografia em Atos, Departamento de Geografia, Faculdade de Ciências e Tecnologia, UNESP, Presidente Prudente, n. 13, v. 06, p. 96-112, Nov/ 2019.

MARTINS, Iracy Coelho de Menezes. Et ali. Diagnóstico ambiental no contexto da paisagem de fragmentos florestais naturais "ipucas" no município de lagoa da confusão, Tocantins. R. Árvore, Viçosa-MG, v.26, n.3, p.299-309, 2002.

MARTINS, José de Souza. Fronteiras: a degradação do Outro nos confins do humano. São Paulo: Hucitec, 1997.

MARTINS, José de Souza. O tempo da fronteira. Retorno à controvérsia sobre o tempo histórico da frente de expansão e da frente pioneira. Tempo Social. Rev. Sociologia. USP, S. Paulo, 8(1): 25-70, maio de 1996.

MARTINS, Sérgio Ricardo Oliveira. Desenvolvimento Local: questões conceituais e metodológicas. INTERAÇÕES Revista Internacional de Desenvolvimento Local. Vol. 3, N. 5, p. 51-59, Set. 2002.

MONBEIG, Pierre. Pionnies et Panteurs de São Paulo. Paris: Armand Colin, 1952. NOGUEIRA, Carlo Eugênio. Fronteiras e frentes pioneiras: aproximações teóricas. Revista Geonorte, Edição Especial 3, V.7, N.1, p.1135-1154, 2013. 
OLIVEIRA, Ariovaldo U. Integrar para não entregar. Políticas públicas para a Amazônia. $2^{a}$ ed. Campinas: Ed. Papirus, 1991.

OLIVEIRA, Gilson Batista de. Uma discussão sobre o conceito de desenvolvimento. Rev. FAE, Curitiba, v.5, n.2, p.37-48, maio/ago. 2002.

PESSÔA, Vera Lúcia Salazar; SANCHEZ, Miguel Cézar. Ação do Estado e as transformações agrárias no cerrado das zonas de Paracatu e Alto Paranaíba - MG.

Boletim de Geografia Teorética. Vol. 19, nº 37-38, AGETEO - Rio Claro - SP, 1989, p.68-79.

PIRES, Mauro O. (1996). Desenvolvimento e Sustentabilidade: um estudo sobre o Programa de Cooperação Nipo-Brasileira para o Desenvolvimento dos Cerrados (PRODECER). Dissertação de mestrado UNB. Brasília: 1996, mimeo, p.200.

PORTO - GONÇALVES, Carlos Walter. A Globalização da natureza e a natureza da globalização. $2^{\text {a }}$ ed. - Rio de Janeiro: Civilização Brasileira, 2011.

PROCÓPIO, Igor Vieira. Et ali. Uso de indicadores de desenvolvimento local: o mapa de exclusão/inclusão social do município de juiz de fora. Revista de História

Econômica \& Economia Regional Aplicada - Vol. 4 Nª 6 Jan-Jun 2009.

SANTOS, Roberto de S. Eixos de Desenvolvimento Regional no Tocantins. In: SANTOS, Roberto. Et alli (Org.). Território e Diversidade Territorial do Cerrado: cidades, projetos regionais e comunidades tradicionais. Goiânia: Ed. Kelps, 2013. p. 135-149.

SEPLAN - Secretaria de Planejamento do Tocantins. Perfil socioeconômico dos municípios do estado do Tocantins, (2010/2013/2014). Disponível em: www.seplan.to.gov.br. Acesso em julho de 2015.

SOUZA, Sônia Maria. Belém-Brasília: abrindo fronteiras no norte goiano (atual Tocantins) - 1958-1975. In: GIRALDIN, Odair (Org). A (Trans) formação Histórica do Tocantins. Goiânia. Ed. UFG. Palmas. Unitins, 2002

Recebido em 23/08/2019.

Aceito para publicação em 20/04/2020. 